\title{
THE NEED FOR A GOOD ENOUGH TERRITORIAL AND ECONOMIC GOVERNANCE IN SOUTH SUDAN
}

\author{
Francis Onditi* \\ Cristina D'Alessandro**
}

\begin{abstract}
Peace and conflict dynamics in South Sudan are intertwined with political governance, institutional capacities, and leadership. Nevertheless, in the specific South Sudanese intractable civil wars since signing of the Comprehensive Peace Agreement in 2005, territorial and economic governance are also certainly strictly connected to any possible prospect of sustainable peace for the country. As such, after carefully defining these concepts, this article emphasizes that territorial governance in South Sudan relates to boundaries definition and to the division of the national territory in states with a certain degree of autonomy. The issues and divergences engendered by territorial governance are intertwined with economic governance concerns. The uneven distribution of natural resources (especially oil) produces wealth and power redistribution concerns that are at the core of contentious relations between social and ethnic groups. These circles of tensions rapidly degenerate into conflict in a context of widespread poverty, inequality, and consequent social vulnerability. The article defines and illustrates a "good enough" territorial and economic governance framework for the South Sudanese case study.
\end{abstract}

Keywords: South Sudan; Governance; Resources; Territory; Political System.

DOI: https://dx.doi.org/10.4314/jsdlp.v8i2.1

* Senior Lecturer \& Head of Department, School of International Relations and Diplomacy, Riara University, Nairobi, Kenya. Email: fonditi@riarauniversity.ac.ke. He previously served as Governance and Political Leadership policy analyst, United Nations Entity for Gender Equality and Women Empowerment, Eastern and Southern Africa Regional Office, Nairobi.

** Senior Fellow at the Centre of Governance at the University of Ottawa, Canada, and a Research Fellow at the Research Centre PRODIG (Université Paris 1 Panthéon Sorbonnne, CNRS), Paris, France and a Professor at the Paris School of International Affairs (Sciences-Po, Paris, France). Previously she served as a Knowledge Expert at the African Capacity Building Foundation in Harare (Zimbabwe) and as a professor at the University Lumière Lyon 2. Email: cdalessa@uottawa.ca 


\section{INTRODUCTION}

Unaddressed issues of territorial and economic governance have trapped South Sudan into cycles and circles of conflicts and tensions. Recent studies reveal other drivers of conflict, including territorial curvatures such as land lordism. ${ }^{1}$ Indeed, some commentators, including the Intergovernmental Authority on Development (IGAD) Chair of the mediation process, Seyoum Mesfin, have said repeatedly that the most pressing issues eroding possibilities for sustainable peace in the country are resource governance and the contentious issue of a federal system. ${ }^{2}$ Political economy discourses have made attempts to construct a nexus between development and governance as the most important gateway to Africa's growth and sustainability. ${ }^{3}$ Whereas, good governance emerges as a key component of African renaissance, fragile states such as South Sudan continue to suffer economic and social injustices embedded in the deep-rooted culture of insurgency leading to intractable political violence, ethnic tensions, agitation for self-rule, and the narrative of power sharing. ${ }^{4}$

Certainly, without any sound political governance, mechanisms for managing the conflict and bringing about sustainable peace remain weak. ${ }^{5}$ The proposed boundaries review process, aimed at creating 28 states, seems to have evoked tensions among some bordering communities, such as Bare and Mundare in Central Equatoria, fighting over boundaries. Indeed, recent studies have concluded that territorial governance issues in South Sudan have strong linkage to the ethnic

1 McMichael, G., "Land Conflict and Informal Settlements in Juba, South Sudan" (2016) 53 (13) Urban Studies 2721-2737.

2 African Union, Report of the Chairperson of the Commission on the situation in South Sudan: Peace and Security Council 515th Meeting at the level of Heads of States and Government, Johannesburg, South Africa, 13 June 2015. < http:// www.peaceau.org/en/article/report-of-the-chairperson-of-the-commission-onthe-situation-in-south-sudan-peace-and-security-council-515th-meeting-at-thelevel-of-the-heads-of-state-and-government> Accessed 22/09/2017).

3 Hanson, K.T., “Managing Africa's Natural Resource Endowments: New Dispensations and Good-Fit Approaches" (2017) 8(1), Journal of Sustainable Development Law and Policy, 122-144.

4 Robertshaw, P., "Prehistory in the Upper Nile Basin" (1987) 28(2) The Journal of African History, 177-189.

5 Beza, Y.T, "Challenges for Peace in South Sudan: Problems and Opportunities of Solving the Current Civil War" (2015) 4 (2) International Research Journal, 4955. 
identities, and that territorial disputes occurred along ethnic cleavages. ${ }^{6}$ All these put together, create legal and administrative ambiguities, hence, leading to conflict over territory, borders and identities. These factors have been fuelling conflict among the Sudanese people from the early 1950s through 1970s. ${ }^{7}$ The history of this country shows that all these bouts of wars and the various attempts at conflict resolution have been derailed by political machinations related to natural resources, without a cohesive and coherent national agenda, and with policies enabling territorial manoeuvres. ${ }^{8}$

The absence of a culture of political dialogue as a means of achieving consensus in addressing political violence has sustained ineffective political governance. ${ }^{9}$ Formal political institutions have been incapable of overcoming the belligerent motives of the leading political elite. ${ }^{10}$ The country is anchored on weak institutions and, therefore, repeated attempts to reach a negotiated peace settlement following the resumption of conflict from mid-December 2013 have failed. ${ }^{11}$ Despite the signing of a Comprehensive Peace Agreement (CPA) on 9 January 2005 , sustainable peace has remained elusive in South Sudan. ${ }^{12}$ The IGAD-facilitated agreement had to deal with the ever-changing multiple demands from Juba and the regional political leaders. ${ }^{13}$ Scholars and

6 Justin, P. H., \& De Vries, L., "Governing Unclear Lines; Local Boundaries as a (Re) Source of Conflict in South Sudan" (2017), Journal of Border Land Studies <http://www.tandfonline.com/doi/full/10.1080/08865655. 2017.1294497> Accessed 22/09/2017.

7 Rolandsen, O.H., "The making of the Anya-Nya insurgency in the Southern Sudan, 1961-64" (2011) 5(2), Journal of Eastern African Studies 211-232; Sambanis, N., "What is civil war?" (2004) 48(6), Journal of Conflict Resolution, 814-858. Sharkey, H., "Arab identity and ideology in Sudan: The politics of language, ethnicity and race" (2007) 107 (426), African Affairs 21-43.

8 Jok, J., Diversity, Unity, and Nation Building in South Sudan (Washington DC, 2012).

9 Straus, S, "Wars do end! Changing Patterns of Political Violence in Sub-Saharan Africa" (2012) 111(443), Journal of African Affairs, 179-201.

10 Seymour, L.J.M., "Let's Bullshit! Arguing, Bargaining and Dissembling over Darfur" (2014) 20(3), European Journal of International Relations, 571-595.

11 Kon, M., "Institutional Development, Governance and Ethic Politics in South Sudan" (2015) 3(147), Journal of Global Economics, 1-6.

12 Kizito, S., "Sudan: Beyond the 2011 Referendum" (2011) 4 (1), African Peace and Conflict Journal, 59-74.

13 During the 2015 review of the IGAD-led South Sudan peace process, attended by IGAD Secretariat led by its Executive Secretary, Mr. Mahboud Maalim; Representatives from the African Union Peace and Security Council and Troika 
policy analysts have also observed that the failure of regional organizations to provide effective mediation stems from their bureaucratic nature, which only permits them to operate within conventional norms. ${ }^{14}$

The Republic of South Sudan is the world's newest nation, born on 9 July 2011. South Sudan has a population estimated at 12 million people spread over an area of $640,000 \mathrm{~km}^{2}$ in 10 states, with a life expectancy of 42 years. ${ }^{15}$ The country has some of the worst development indicators on the African continent and, therefore, in the world. Nationally, 51 per cent of the population lives below the poverty line (55 per cent in rural areas and 24 per cent in urban areas). ${ }^{16}$ Eighty per cent of the poor households depends on agriculture for their livelihood. ${ }^{17}$ The country experiences the double tragedy of conflicts as well as humanitarian catastrophes. ${ }^{18}$ Studies have indeed revealed a correlation between climate variation and conflict occurrence, especially among pastoral communities, the Dinka and the neighbouring Acholi people, who are mainly sedentary. ${ }^{19}$ The livelihood situation is, however, compounded by other security-related complexes, such as the need to conduct an effective demobilization, disarmament and reintegration of former combatants. ${ }^{20}$ Education and health indicators

members-UK, US and Norway, IGAD reiterated that its mandate would be reviewed in line with emerging priorities and challenges, including: the killing of Ethiopians in Libya; the Xenophobic attacks in South Africa; the uncontrolled refugee flow from Yemen to Ethiopia, Djibouti and Eritrea

14 Pinfari, M., "Interregionalism and Multiparty Mediation: The Case of Arab Africa" (2013) 18(1), International Journal of Peace Studies, 83-101.

15 Government of the Republic of South Sudan, South Sudan Development Plan 2011-2013: Realizing Freedom, Equality, Justice, Peace and Prosperity For All. Ministry of Finance and Economic Planning. Government of South Sudan, August 2011.

16 Elryah, Y., "Back to Agriculture - The Development of the Comparative Advantage of Sudan's commodities" (2015) 3(1), Journal of Finance and Economics, 1-5.

17 Enough Project Sudan and South Sudan, Center for American Progress (Washington, DC, 2015) < http://www.enoughproject.org/conflicts/sudans >

18 International Federation of Red Cross and Red and Red Crescent Societies; Development Operational Plan South Sudan, IFRC, 2014. < http://reliefweb.int/ sites/reliefweb.int/files/resources/MAASS001_14DOP.pdf> Accessed 22/09/ 2017.

19 Maysdt, J-F., Calderone, M., and You, L., "Local Warning and Violent Conflict in North and South Sudan" (2014) 15 (3), Journal of Economic Geography, 649671.

20 Munive, J., "Invisible labour: The Political Economy of Reintegration in South Sudan" (2014) 8 (4), Journal of Intervention and Statebuilding, 334-356. 
are among the lowest in the world, reflecting the impact of protracted conflict and limited provision of social services. As it commonly happens in post-conflict societies, the failure in political institutions to create functional relationships between the rulers and those who are ruled leads to skewed decision-making rights, excluding the bulk of the population from the access to state and general public resources and opportunities. ${ }^{21}$

The 2016 Fragile States Index placed South Sudan on top of the "very high alert", on a scale of 113.8, just slightly behind Somalia (114.0). ${ }^{22}$ This dispels off prospects for foreign direct investment (FDI) and disrupts people's livelihoods. The country continues to experience humanitarian catastrophes, internally displaced persons (IDP), group grievances, a fictionalized elite, and human rights violations, significantly threatening the capacity of the state to face them.

The country is, in fact, emerging from the longest and most destructive war in African history, which left over 2 million people dead and at least 400,000 South Sudanese who fled to neighbouring countries by July 2014 in exile. The country anticipates about 715,000 refugees in the years to come. ${ }^{23}$ As might be expected in such a fractious society, famine and sexual violence have increased dramatically, just as social tensions and violence have returned to the forefront of the intraSouth Sudanese relations. ${ }^{24}$ South Sudan may be defined both as a post-conflict state, which is recovering from 50 years of war and also as a state that continues to suffer from conflict in the form of militia activity and inter-communal violence. These conflicts, fought between the Sudanese government and movements arising within Sudan, are commonly rooted in the unequal distribution of power and wealth

21 Wennmann, A., Sahring, "Natural Resources Wealth During War-To-Peace Transition" In P. Lujala and S.A. Rustad (eds) High Value Natural Resources and Peacebuilding (London: Earthscan, 2012), 225-229. Also see, Wolf, S., "PostConflict State Building: The Debate on Institutional Choice" (2011) 32 (10), Third World Quarterly, 1777-1802.

22 The Fund for Peace, "Fragile states index 2016," Foreign Policy Magazine (Washington D.C., 2016).

23 Jack Radden, "UNHCR Seeks Massive Boost in Funding For South Sudan Refugees," UN High Commissioner for Refugees (11 July 2014) < http:// www.unhcr.org/53bfdc1a6.html>

24 Johnson, D., "Briefing: Crisis in South Sudan" (2014) 113 (451), African Affairs 300-309 ; Deng, L.B., "Social Capital and Civil War: The Dinka Communities in Sudan's Civil War" (2010) 109 (435), Journal of African Affairs, 231-250. 
among the Sudanese population. ${ }^{25}$ Most of the literature on the politics of South Sudan emphasize the repulsive South-North relations and paucity of resource. ${ }^{26}$ Yet, the Anglo-Egyptian Condominium (18991956) policy has generated political tensions even after the secession of the Southerners. The British administration applied this policy selectively, producing a further marginalization of the black South Sudanese and leading to the formation of rebel movements. ${ }^{27}$ The latency of conflict in the country is undebatable. ${ }^{28}$

Some scholars observe that the decentralized form of government has exacerbated social and regional tensions in South Sudan. ${ }^{29}$ For instance, the concept of Equatorians as a social group is based on a cluster of 36 tribes that managed to construct a common regional identity. ${ }^{30}$ Bahr el Ghazal and Upper Nile regions have failed to recognize and adopt such regionalized identity over ethnic and tribal identities. As stipulated in the peace accord, institutional arrangements that promote consociational governance help promote inclusive governance in divided societies. ${ }^{31}$ In South Sudan, inclusivity, arguably, can be instrumental in contributing to the evolution of a political architecture that will eventually minimize the Dinka and Nuer's hegemony in the country's governance. However, this article does not directly focus on political governance, peace mechanisms, and conflict management, as

25 Sriram, C. and Zahr, M-J., "The Perils of Power-Sharing: Africa And Beyond" (2009) 44 (3), Africa Spectrum 11-39; Stedman, S.J., "Spoiler Problems in Peace Processes" (1997) 22, International Security, 5-53.

26 Young, J., "Sudan: A Flawed Peace Process Leading to a Flawed Peace" (2005) 32 (103), Review of African Political Economy, 99-113; Zonkosi, Z., "Sudan Caught between Colonial Remnants and Oil Revenue" (2004) 1 (1), African Renaissance, 74-77.

27 Collins, R., Shadows in the grass: Britain in the Southern Sudan, 1918-1956 (New Haven, Yale University Press 1983); Johnson, D., The Root Causes of Sudan's Civil Wars: Peace or Truce (Oxford: Currey, 2011).

28 Astill-Brown, J., South Sudan's Slide into Conflict: Revisiting the Past and Reassessing Partnership (Africa Programme, The Royal Institute of International Affairs, Chatham House 2014).

29 Kabbede, G., "Sudan: The North-South Conflict in Historical Perspective" (1997) 15(1) Contributions in Black Studies 1-31. < http://scholarworks.umass.edu/ cibs/vol15/iss $1 / 3>$.

30 Markakis, J., National and Class Conflict in the Horn of Africa (Cambridge University Press, Cambridge, 1987).

31 Lijphart, A., "Review Article: The Northern Ireland Problem; Cases, Theories, and Solutions" (1975) 5, British Journal of Political Science, 83-106. 
there is a plethora of literature on these issues. ${ }^{32}$ It rather highlights and analyses the territorial and economic governance dimensions in South Sudan.

The article has six sections. After this introduction, section 2 presents the specific governance framework used in the text. Section 3 focuses on territorial and economic governance, as complementary and interrelated angles to analyse the South Sudanese situation. Section 4 presents the critical features of a "good enough" governance framework in South Sudan, while section 5 analyses the practical challenges and offers a few recommendations on how to deepen the approach in South Sudan. Section 6, the concluding part, offers some final remarks.

\section{A SPECIFIC GOVERNANCE FRAMEWORK}

The commonsense of governance as "a given process of governing" independently from the entity (public or private) and modalities (e-governance, corporate, public sector, etc.) of this "mode of government", is widely used in the academic world and in policymaking. Despite theoretical and operational differences, good governance is generally used to describe contexts and situations in which the mechanisms of governing function properly from a political and economic point of view. ${ }^{33}$

In recent times, especially in developing contexts in which capacity gaps are important and undermine good governance, a good fit governance ${ }^{34}$ or a good enough governance ${ }^{35}$ have been theorized and deemed more appropriate for fragile states, post-conflict countries, and developing contexts in general. The idea behind this move is that in a

32 Steven C. Roach, "South Sudan: A Volatile Dynamic of Accountability and Peace" (2016) 92 (6), International Affairs, 1343-1359; Alex De Waal, "When Kleptocracy Becomes Insolvent: Brute Causes of the Civil War in South Sudan" (2014) 113 (452), Journal of African Affairs, 347-369; Johnson H. Douglas, "Briefing: Crisis in South Sudan" (2014) 113(451), African Affairs, 309.

33 Grindle, M.S., "Good Enough Governance Revisited” (2007) 25 (5), Development Policy Review, 533-574.

34 Owusu, F., D'Alessandro, C. and Hanson, K, "Moving Africa beyond the Resource Curse: Defining the "Good Fit," "Approach in Natural Resource Management and Identifying the Capacity Needs" in: Hanson, K.T., D'Alessandro C. and Owusu, F. Y. (eds.) Managing Africa's Natural Resources: Capacities for Development (Houndmills, Basingstoke, Palgrave Macmillan (2014), 206-225.

35 Grindle, M.S, Good Enough Governance Revisited: A Report for DFID with Reference to the Governance Target Strategy Paper (Harvard University Feb 2005). 
real world context with limited capacities and resources (both financial and eventually human), the focus for practitioners and social scientists is to modestly aim at better governance, instead of trying to achieve an ideal that is impossible in the prevailing contexts. Given the South Sudanese situation presented thus far and using a good enough governance approach, this article examines the critical issues of territorial and economic governance, as well as their interconnections with the political system of governance.

Territorial governance may be defined in multiple ways in political geography and in geopolitics. It generally refers to the organization and coordination capacity of public and private stakeholders to transform a given territory. ${ }^{36}$ It denotes, for the specific focus of this article, the mechanisms aimed at governing a national territory and its parts (mainly South Sudanese states here), referring to the challenges, policies, and stakeholders' strategies.

Being exerted on a territory with resources, territorial governance also has a critical economic dimension, called economic governance. Adhering to this vision, and given the state and its territory as appropriate references for economic boundaries for this study, economic governance is defined accordingly as the complex processes permitting and modifying the distribution of national economic resources among the various stakeholders. Concerns regarding access to economic resources and the actions of those controlling the levers of economic power are acute in contexts like South Sudan, where particular groups have been historically marginalized. When grievances related to unfair distribution of economic revenues or resource wealth provoke civil wars, the objective of rebel groups is to gain control over certain resource-rich areas, like the oil-producing states in South Sudan. Wealthsharing arrangements seek to manage access to revenue sources and, consequently to create opportunities for renewed conflicts.

In South Sudan, peace and conflict are intrinsically related to economic governance, with concerns about wealth and revenues produced by oil exploitation, inequalities, and rights of various groups. This crucial question has a territorial dimension linked to the boundaries and to the definition of states, with consequences for the oil producing

36 Davoudi, S., Evans, N., Governas, F., and Santangelo, M., "Territorial Governance in the Making: Approaches, Methodologies, Practices" (2008) 46 Boletin, de la A.G.E 33-52. 
states. This article demonstrates that without any sound and collaborative territorial governance ${ }^{37}$ (and subsequent economic governance), South Sudan cannot hope to achieve any good enough political governance leading to real and sustainable peace and stability.

\section{TERRITORIAL AND ECONOMIC GOVERNANCE}

In fragile and post-conflict states, such as South Sudan, territorial governance necessarily goes through the effort to rebuild structures and institutions at the local and national level. ${ }^{38}$ Territorial governance calls for the devolution of powers from the central government to local and regional institutions. Federalism, the most commonly used approach, describes a system in which the national territorial power is shared between multiple levels of government as a means of combating social or regional divisions. This system of multi-tiered government, or partitioned decision-making, includes a constitutionally entrenched division of power between the central government and federal subunits. ${ }^{39}$ If this should work well in theory, the linkages between economic resources (and interests) and territorial governance continue to pose threats to decentralized territorial governance in South Sudan. It is for this reason that this article asserts that the path to sustainable peace in the country is intertwined between economic development, good governance and democratic transformation.

South Sudan has tried several times to put into practice this conceptual linkage. The 29 April 2016 Administrative Arrangement set in place following the peace agreement signed in August 2015 is one of these attempts. The August 2015 Compromise Agreement provided the rebels with a share of power throughout the country. In the three Greater Upper Nile states, the percentages of rebels in the government were 46 for the government, 40 to the Sudan People's Liberation Movement in Opposition (SPLM-IO), and 14 to the other political parties. In Greater Bahr al Ghazal and the three states in Equatoria, the government secured a majority of 80 per cent, while the

37 Chris, A. and Alison, G., "Collaborative Governance in Theory and Practice" (2007) 18, Journal of Public Administration Research and Theory, 543-571.

38 Berge, E. and Benporat, G., "Introduction: Partition vs. Power Sharing" (2008) 14(1), Nations and Nationalism, 29-37.

39 Pospiesna, P. and Schneider, G., "The Illusion of Peace through Power-Sharing: Constitutional Choice in the Shadow of Civil War" (2013) 15, Civil Wars, 50. 
SPLM-IO received 15 per cent, and the other parties 5 per cent. Additionally, the rebels were allowed to nominate the governors of Upper Nile and Unity states.

As aforementioned, IGAD brokered the 2016 Peace Agreement with support from East African Community (EAC) member states and their continental and international partners. The main mechanism for delivering the agreement and monitoring the governance deal is the Agreement on the Resolution of the Conflict in South Sudan (ARCISS) ${ }^{40}$ At this time, the Transitional Government of National Unity (TGoNU) was designed to administer the country for the next two and a half years, in preparation for the general election. In many ways, the April 2016 agreement in the TGoNU is a return to the previous status quo. The peace agreement was established on the understanding that boundaries' review had to be immediately commissioned to create the 28 states.

In South Sudan, the call for federalism remains strong. In fact, like any other state with history of social unrest and conflict, South Sudan is rooted in the fear of any possible political and economic domination. ${ }^{41}$ From 1956 to 2005, successive civil wars were fought over issues related to the centralization of power and resources by a minority of northern mixed-Arab tribes. ${ }^{42}$ During the rather short time of peace under the Addis Ababa Agreement from 1972 to 1983, the government in Khartoum provided a certain degree of regional autonomy to the south. During the presidency of Jafaar al-Nimeiri, the divisions in the south were reshuffled periodically and regional governments dissolved. These moves eventually led to a resumption of conflict in 1983. When the CPA was signed in 2005, the SPLM was

40 The issues that the South Sudan transition government with the help of an external oversight through the Join Monitoring and Evaluation Commission (JMEC), led by former president of Botswana, Festus Mogae, set to address were to: (1) tackle insecurity and ensure total silence of the guns; (2) revive the economy and reduce wastage and corruption; (3) Institute National Dialogue and reconciliation; (4) promote equal opportunities in employment for all regions and encourage equitable resource allocation; (5) Improve on service delivery (education, health and water); (6) Make government appointments to reflect ethnic diversity, merit, competence and knowledge.

41 Adeba, B., Making Sense of the White Army's Return in South Sudan (Centre for Security Governance, CSG, Paper No. 1, 2015).

42 Randon, J. and Logan, S, "South Sudan: Governance Arrangements, Wars and Peace" (2014) 68(1) Journal of International Affairs 147-167 <http:// jia.sipa.columbia.edu/south-sudan-governance-arrangements-war-peace $>$. 
granted almost complete autonomy within a Sudanese federation, an arrangement that the population ultimately rejected when it voted for independence in $2011 .{ }^{43}$

After the successful CPA in 2005 and subsequent secession referendum in 2011, South Sudan emerged as a nation inheriting a system of ten states. ${ }^{44}$ Since signing the CPA, the SPLM government has been accused of diverting resources away from the Nuer lands, where the country's oil fields are located, to develop Juba, Bahr el Ghazal, and other mainly Dinka areas. Along the streets of Juba, one can hear voices suggesting that Juba has become the "new north", that oil is drained from the Unity State and food from the Greater Equatoria to the benefit of soldiers living in barracks. This reveals how the partition of the national territory in states and territorial governance are deemed important and unfair for some parts of the population. Although the Constitution invokes the principle of decentralization, South Sudan has become a unitary state in which political power is almost entirely vested in the central government. In the agreement, the word "federalism" appears in the text without providing further details as to what it entails. Machar's faction had demanded that a federal arrangement should have been agreed upon, as part of a final peace agreement, while President Kiir's government insisted that the matter should be referred to a constitution-making process for consideration. ${ }^{45}$

Aside from the ruling government, there was a broad agreement between all other stakeholders at the peace talks that federalism represents a preferable and more equitable system for South Sudan. The centralization of power and resources within an ethnically or regionally defined group of elites is, in fact, an important driver of conflict in the country. By devolving power and access to resources at the sub-national level, it is argued, local actors will be granted a measure of self-determination that may work towards overcoming South Sudan's many internal divisions. Through regional autonomy, states are given

43 Johnson, D., Federalism in the History of South Sudanese's Political Thought (Rift Valley Institute, London, United Kingdom 2014).

44 Chol, T.T., "Why the SPLM-IO Calls for Federalism in South Sudan" (2015) Nyamilepedia (8 April 2015).

45 Intergovernmental Authority on Development: Agreement on the Resolution of the Conflict in the Republic of South Sudan, Addis Ababa, 17 August 2015: http://nyamile.com/2015/08/18/revised-igad-plus-compromise-peaceagreement-august-17-2015/. 
some freedom to run their affairs, provided a share of resources, and the ability to use them in their own way. Federal arrangements are widely regarded as having greater ability than unitary governance structures to mitigate conflict in countries defined by social or territorially-based divisions. Ethiopia is, for instance, frequently presented as a model of ethnic federalism. ${ }^{46}$

A number of complications arise from the fact that the parties to a federal government often have very different expectations and criteria for success. Political leaders in the central government are typically driven by the expectation that some dispersal of power will avoid conflict by addressing certain demands of communities and social groups. ${ }^{47}$ Given the asymmetries between the central government and federal sub-units, many arrangements are in essence imposed from the top, with the support of only a segment of the regional elite. One of the primary demands of the SPLM-IO has been that a federal structure had to be implemented immediately during the transitional period. The SPLM-IO's plan during the mediation was to expand the current system of 10 states to 21, based on the colonial districts that existed in 1956 . According to Fana Gebresenbet, this proposal threatens to take the Ethiopian example to the extreme by creating a multiplicity of weak states that are unable to challenge or restrain the federal government. Nevertheless, Ethiopia, as a society, has evolved over several decades and its economic basis is more diversified compared to newly created Republic of South Sudan. ${ }^{48}$ The latter over-relies on oil extraction, yet this resource is not evenly distributed across the country.

All along, the SPLM-Juba's position has been that any discussion of adopting a federal system did not have to be negotiated in Addis Ababa and should have be implemented instead after a lengthy process of national "consultations". After having rejected the SPLM-IO's proposal to create 21 states at the negotiating table, President Kiir issued a decree in October 2015 with a design of 28 states. ${ }^{49}$ This move was a

46 Gebresenbet, F., "Land acquisitions, the Politics of Dispossession and StateRemaking in Gambella, Western Ethiopia” (2016) 51 (1), Africa Spectrum, 5-28.

47 Mengistead, K., "Identity Politics, Democratization and State-Building in Ethiopia's Federal Arrangement" (2007) 7, African Journal on Conflict Resolution, 2.

48 Villers, B., "Federalism in South Sudan-Options for Power Sharing in the Permanent Constitution" (2014) 9(6), Journal of Asian and African Studies, 654-671.

49 Adeba, B., "Splitting South Sudan into 28 States: Right Move, Wrong Time?" (2015) African Arguments, 7 October. 
clear abrogation of the peace agreement, which was based on the current 10-state structure and called for further negotiations regarding the final make-up of any federal structure. In reality, the most significant stipulations of the August 2015 agreement provided to the rebels, and the governorship of the oil-producing Unity and Greater Upper Nile states. This edict would override those provisions by carving up the country largely along ethnic lines, splitting the two states into seven and leaving the Nuer cut off from the oil-producing regions. ${ }^{50}$

The CPA was mainly designed to address the issues of the South. The rebellions in Darfur to the West, the Beja in the East and along with the border regions of South Kordofan, Blue Nile and Abyei stemmed in large part from this lack of inclusivity. ${ }^{51}$ South Sudan is composed of 64 ethnic groups, of which the Dinka and Nuer are the largest, an estimated 35.8 and 15.6 per cent, respectively. ${ }^{52}$ It must be recognized that even within these seemingly cohesive ethnic or regional categories, many divisions exist. Despite some diversity within both warring parties, many South Sudanese perceived the negotiations as if half of the population was carving up the entire national pie. The "Equatorians" are the most prominent example of a group that was, for the most part, left out of the negotiations over federalism. This group comprises three states in South Sudan populated by a wide diversity of small tribes. Though the people of Equatoria and their delegates have remained steadfast in their calls for federalism, these desires have been caught in between the plans of the government and rebels. ${ }^{53}$ There have been, in fact, minimal attempts to involve marginalized social groups or civil society in the discussion on either side. Though the calls in favour of federalism are overwhelming in South Sudan, the actual design and logistics of implementing any federal system are considerably less clear. Besides, Oystein Rolandsen in his seminal article in the Journal of Eastern African Studies, poses an interesting question pointing to three major structural problems that this country continues to suffer from: neo-patrimonial politics, weak

50 Sharon Hutchinson, Nuer dilemmas: Coping with War, Money and the State (Berkeley, University of California Press, 1996).

51 Kabbede (n 29).

52 Jok, M.J., and Hutchinson, S.H., "Sudan's Prolonged Second Civil War and the Militarization of Nuer and Dinka Ethnic Identities" (2014) 4(2), African Studies Review, 125-145.

53 Kebbede (n 29). 
state structure, and legacies of violence from the previous civil war. ${ }^{54}$

Efforts to centralize power, a fundamental element of the process of state formation despite its associated challenges in the South Sudanese context, have historically been deeply divisive in the country. ${ }^{55}$ Thus, it is imperative to strike a balance between the strength of both central and state governments with a view to achieving a good enough territorial governance.

Despite the merits attributed to power sharing as a method of conflict resolution, Donald Horowitz, raises concerns that three problems must be internalized by mediators: (1) the adoption problem; (2) the degradation problem; and (3) the immobilism problem. ${ }^{56}$ In the case of South Sudan, the glaring injustices and unbalanced territorial governance between the central and local level make it hard to execute principles and tools of economic governance. James Cust and Toffin Harding articulate the effects of the conflict in South Sudan, observing that the economic prospects of the country were far more positive than the ones of other economic giants in the region. Indeed, during this pre-conflict period, the International Monetary Fund (IMF) indicated that South Sudan's gross domestic product (GDP) per capita was US\$1,822, compared to Kenya's US\$ 839, Uganda's US\$528, and Ethiopia's US $\$ 371 .{ }^{57}$ This impressive economic outlook deteriorated rapidly after the country slid back into civil war, instigated by political power-sharing disagreements. The April 2016 political arrangement was to offset fears that critical state resources like oil could be concentrated in the hands of the Dinka and Nuer. For this reason, the South Sudanese national leadership tried to set in place policies for the distribution of state resources capable of achieving a stable balance among competing groups, in essence the Dinka and Nuer, in relation to their control over economic resources.

South Sudan exhibits two interconnected mechanisms of economic

54 Rolandson, O.H., "Another Civil War in South Sudan: The Failure of Guerrilla Government?" (2015) 9 (1), Journal of Eastern African Studies, 163-174.

55 Villiers, B., "Federalism in South Sudan-Options for Power Sharing in the Permanent Constitution" (2014) 49(6), Journal of Asian and African Studies, 654-671.

56 Horowitz, D., "Ethic Power Sharing; Three Big Problems" (2014), Journal of Democracy, 255-20.

57 International Monetary Fund, "World Economic Outlook (WEO); Transitions and Tensions: World Economic and Finance Surveys", October 2013; < http:// www.imf.org/external/pubs/ft/weo/2013/02/>. 
governance: wealth redistribution among specified communities (Nuer and Dinka) and resource power allocation that is giving rebel groups resource control in the government. ${ }^{58}$ Wealth sharing refers to a negotiated agreement that determines the distribution of income derived from oil, other mineral resources, and other state revenue streams. By distributing the 30 government positions to different rebel groups (resource power allocation), Kiir and Machar were simply exercising a wealth-sharing strategy suited for a post-conflict situation, in which leaders allocate decision-making power over oil, other strategic resources, and state finances to representatives of rebel groups. ${ }^{59}$ This selective distribution of wealth and state power presents several complications in its implementation. First, there is a potential for the government to impede implementation or for the rebels, along with groups excluded from the process, to end up as spoilers.

Second, the incapacity of a party to enforce an agreement within its own ranks can lead to a resumption in fighting by splintering factions that reject its content. Third, signatories are often duplicitous and use an agreement for tactical reasons to achieve their military objectives. Furthermore, the parties often do not encompass all actors with a capacity to prolong the conflict. The assumption is that meeting the economic demands of rebel groups will dis-incentivize further rebellion, but giving them access to state resources bolsters their power bases and can increase the rationale for using violence as a bargaining tactic. ${ }^{60}$ Wealth sharing, by design, institutionalizes access to state resources for the government and rebels. This politically driven distribution of state assets and positions is accompanied by a tacit agreement on corruption that is informally embedded into any peace accord. ${ }^{61}$ By essentially "buying off" armed opponents, wealth sharing brings rebel groups into existing systems of patronage. ${ }^{62}$

58 Binningsbo, H.M. and Rustard, S.A., "Sharing the Wealth: A Pathway to Peace or a Trail to Nowhere?" (2012) 29(5), Conflict Management and Peace Science, 548-555.

59 Kaplan, S., "Countering Centrifugal Forces in Fragile States" (2016) 39, The Washington Quarterly, 69-82.

60 Le Billon, P., "Natural Resource Types and Conflict Termination Initiatives" (2009) 70, Colombia International, 27.

61 Ottaway, M., "Promoting Democracy after Conflict: The Difficult Choices" (2003) 4(3), International Studies Perspective, 314-322.

62 Nitzschke, H. and Studdard, K., "The Legacy of War Economies: Challenges and Options for Peacemaking and Peacebuilding" (2005) 12 (2), International Peacekeeping, 222-239. 
Through the IGAD-led negotiations, Dr Riek Machar was reinstated as the First Vice-President, legitimately representing the Nuer, accounting for more than 15 per cent of the total population and by extension representing other ethnic groups who were felt left out by Kiir's government. Thus, as already emphasized, the April 2016 arrangement is nothing less than the previous arrangements and the (re)distribution of power between these elites is perfecting conditions for an intractable conflict. Restrain is henceforth required in relation to the capacity of this agreement to advance governance in South Sudan, because there are obvious stress points in the new political architecture making problematic economic governance. The deplorable economic governance situation in the country has been attributed to the current militarization of the development process. ${ }^{63}$ Militarization seems to diverge efforts towards democratization of the South Sudanese society. ${ }^{64}$

However, the absence of a full democracy is not unique to South Sudan. Studies across the globe show a correlation between levels of development and archetype of democratization. ${ }^{65}$ There is, however, a general consensus that globally the democratization outlook has become impressive since the fall of the Berlin Wall in 1989. But, this is not always the case, especially in fragile states where the weak forms of democratic structures represent both political and developmental problems. For instance, the trend spanning over 30 years (1970-2007) indicates that 36.5 per cent of countries are still under the yoke of authoritarian regimes, 37.2 per cent are silently persevering flawed democracies and 14.0 per cent are surviving hybrid regimes. ${ }^{66}$ The same study shows that only 12.3 per cent live in full democracies. Although, the archetype of "democracy" dominating the literature has been contested as being overly west-phalian, most scholars have agreed that

63 Radon, J. and Logan, S., "South Sudan: Governance Arrangements, Wars and Peace" (2014) 68 Journal of International Affairs 1 <www.questia.com/library/ journal/1G1-396527047/south-sudan-governance-arrangements-war-andpeace $>$

64 Rolandsen, O.Y., Glomnes, H.M., Manoeli, S., and Nicolaisen, F., "A Year of South Sudan's Third Civil War" 18(1) (2015), International Area Studies Review, 87104.

65 Toledo, A., Carothers, T., Levy, B. Wollack, K. and Hubli, K.S., "Democratization and Development" (2010) 21(4), Journal of Democracy, 13-26.

66 Besley, T. and Robinson, A. J., "Quis Custodiet Ipsos Custodes? Civilian Control over the Military" (2010) 8, Journal of the European Economic Association, 655663. 
the civilian government needs the army to avoid internal violence, but a larger army reduces the opportunity-cost for the military to run a coup d'etat and seize power. ${ }^{67}$

This implies that lower levels of income per capita increase the probability of militarization of security agencies. ${ }^{68}$ Consequently, a militarization behaviour among those in power is most likely to "breath" high levels of income inequalities and ethnic fractionalization. ${ }^{69}$ In the same vein, some scholars have argued that, contrary to the popular view that dangers posed by military rule relate to its intrinsic authoritarian regime, ${ }^{70}$ it is the patrimonial tendency in military rule that creates the most transcendent and pernicious effects on democracy. South Sudan's bouts of conflict and the successive peace-making attempts divulge a vicious inter-ethnic acrimony and rivalry, particularly between the Dinka and Nuer. In 2013, Dr Riek Machar exploited this tone and managed to delegitimize the government of President Salva Kiir creating a hostile environment and eliminating prospects for the growth of a political architecture based on the principles of democracy.

An overdependence on oil revenue is a consequence of weak institutional governance architecture that is conducive to conflict. ${ }^{71}$ The country heavily relies on oil revenue to fund about 80 per cent of its budget. ${ }^{72}$ Observably, output has reduced significantly since the country slid into conflict in 2013, coupled with the rapid decline in oil prices. In 2014, total income from oil stood at US\$3.38 billion. ${ }^{73}$ However, after deducting US\$884 million in payments due to its neighbour, Sudan, and the US\$781 million loan repayments to donors and international financiers, South Sudan was left with just US\$1.715

67 Costa, J., Caruso, R and Riciuti, R., The Probability of Military Rule in Africa 1970-2007 (Working Paper No. 17, Department of Economics, University of Verona, Italy, 2012).

68 Besley, T. and Persson, T., "Wars and State Capacity" (2008) 6(2-3), Journal of the European Economic Association, 522-530.

69 Binningsbo H. and Rustard, S.A., "Sharing the Wealth: A Pathway to Peace or a Trail to Nowhere?" (2012) 29(5), Conflict Management and Peace Science, 548555.

70 Ikpe, B. U., "Patrimonialism and Military Regimes in Nigeria" (2000) 5(1), African Journal of Political Science, 146-162.

71 Radon, J. and Logan (n 63).

72 Perlo-Freeman, S., Fleurant,A., Wezeman, P. and Wezeman, S, Trends in World Military Expenditure, 2015 (Stockholm International Peace Research Institute, SIPRI, Stockholm, Sweden, 2016).

73 ibid. 
billion from oil revenue. During the same financial period, South Sudan's military spending rose to US $\$ 1.08$ billion, up from US $\$ 982$ million in 2013. ${ }^{74}$ This means that Juba spent more than 60 per cent of its net oil revenue on the military. The high military spending trend in the youngest African nation continues to widen the question of governance and political leadership in Juba, especially now that the African military expenditure fell by 5.3 per cent in 2015, reaching an estimated US\$37.0 billion, following 11 continuous years of rising spending. Total spending in 2015 remained 68 per cent higher than in $2006 . .^{75}$

As a result, the failure of the political institutions to create functional relationships between the rulers and those ruled that leads to skewed decision-making rights excludes the rest of the population from accessing both state and general public resources and opportunities. It is for this reason that institutional theoreticians assert that multiple dimensions (political, military, territorial, etc.) of powersharing in a peace agreement are expected to have a cumulative effect on the actors' sense of security (in all forms, including livelihood, protection and wealth), with the different forms becoming mutually reinforcing. ${ }^{76}$ In fragile states such as South Sudan, former combatants require assurances that no single group will be able to use the power of the state to secure what they failed to win on the battlefield. Nevertheless, if the governing institutions are well articulated, they could, to a large extent, promote a moderate and cooperative behaviour among contending groups by guaranteeing each group a share of state power.

In all these clouds of unsuccessful peace deals, a fundamental problem has been that the political elites have failed to appreciate that governing institutions are most likely to suffocate if not anchored on democratic principles. ${ }^{77}$ Like many other peace deals signed in this

74 Editorial, "South Sudan Military Spending Doubles to US\$1bn, Highest in Region" The East African (25 April 2015). <http://www.theeastafrican.co.ke/news/ South-Sudan-military-spending-doubles-to-1bn/-/2558/2697206/-/ 9ibjm6z/-/index.html>

75 ibid.

76 DiMaggio, J. P. and Walter, W. P., "The Iron Cage Revisited: Institutional Isomorphism and Collective Rationality" in Walter W. Powell and Paul J. DiMaggio (eds.), The New Institutionalism in Organizational Analysis (Chicago, IL: University of Chicago Press: 1991), 63-82.

77 Ottaway, M., "Promoting Democracy after Conflict: The Difficult Choices" (2003) 4, International Studies Perspective, 314-322. 
country, the April 2016 arrangements seem to be at the mercy of the commanders of SPLM and SPLM-IO principals, respectively. The intersection of these forces produces a negative peace that reflects nothing less than fear and internal resistance to the implementation of a genuine peace agreement. This state of affairs does not necessarily depart from what was witnessed since the signing of the CPA in 2005, when parties to the conflict retained their loyalties to their ethnic and military cleavages. ${ }^{78}$ In an effort to arrive at a settlement, amid pressures from both internal and international sources, the IGAD-plus mediators have unfortunately promoted negotiation processes and agreements that fundamentally lack the democratic values they ostensibly represent. To chart a progressive path for the peace processes to thrive in deeply divided societies such as South Sudan, ${ }^{79}$ this article points out four key features of a good enough governance system, as illustrated in the following section.

\section{TOWARDS GOOD ENOUGH GOVERNANCE IN SOUTH SUDAN}

A good enough governance system may be difficult in South Sudan, but it is not impossible. This section of the article states that, for this specific case study, the governance system must have four major features: (1). It must set in place some sort of modest and limited decentralization; (2). It has to go through a collaborative process, involving as much as possible representatives of the different social groups; (3). Efforts towards economic diversification have to be made in a realistic way; and (4). More than tribal/ethnic issues, conflicts in the country are related to access and rights to strategic resources: inequalities and injustices to this extent must be progressively addressed.

It has been highlighted in the previous section that a real federalism with a completely decentralized political and administrative system is

78 Mac Ginty, R., "Hybrid peace: The Interaction between Top-Down and BottomUp Peace" (2010) 41(4), Security Dialogue, 391-412.

79 Van Leeuwen, M. \& Verkoren, W., "Complexities and Challenges for Civil Society Building in Post-Conflict Settings" (2012) 7 Journal of Peacebuilding \& Development 81-94; Organization for Economic Cooperation and Development, "Concepts And Dilemmas of State Building In Fragile Situations; From Fragility To Resilience" (Discussion Paper 9, No. 1, 2008) < https://www.oecd.org/dac/conflict-fragilityresilience/docs/41100930.pdf> 
a problematic goal nowadays in South Sudan, given the legacy of conflicts, the fragmented social system, and the widespread corruption entrenched in the way institutions and administrations function. The explanation of the contemporary need to decentralize state activity and the challenges arising therefrom have also demonstrated the critical necessity of some sort of modest form of decentralization. This means that one has to be conscious that it is practically impossible nowadays to find an agreement and set in place a real and well-functioning decentralized state system in South Sudan. It would, however, be dramatic for the country to abandon any ambition to this extent under the pretext that every attempt has failed in the past and that the state is not likely to be able to achieve this goal. This article consequently proposes a modest decentralized system, only limited to a sector or a specific goal and task, but of critical importance for the society. In line with what is stated in official South Sudanese documents, the different local and regional levels of government could serve to support the central government to deliver services to the people. ${ }^{80}$ This would not be enough to bring development to them, but service provision is an essential component of it. Again, maybe not all the services could be well and entirely provided, but local governments could find the way to interact with superior levels to make progress for services of critical importance, driving some development for the population. If done in an equitable way, targeting the most vulnerable communities and groups, it can be assumed that this would contribute towards decreasing conflict at the local level, especially among the rural communities.

A good enough governance approach must in fact be collaborative, ${ }^{81}$ also called participatory, ${ }^{82}$ or inclusive. ${ }^{83}$ These different adjectives similarly refer to the various steps or attempts to include as much as possible minorities and vulnerable groups, stakeholders, and citizens

80 Munive, J., "Invisible Labour: The Political Economy of Reintegration in South Sudan" (2014) 8(4), Journal of Intervention and Statebuilding, 334-356.

81 Chris, A. and Alison, G., "Collaborative Governance in Theory and Practice" (2007) 18, Journal of Public Administration Research and Theory, 543-571.

82 Francesco, M. and Veronica, R., "A Participatory Governance Model towards the Inclusion of Ethnic Minorities. An Action Research Experience in Italy" (2015) Interventions Économiques $53<$ http://interventionseconomiques.revues.org/ 2609>

83 Eiman, K. and Inga, J-M, "Inclusive Governance: The Role of Knowledge in Fulfilling the Obligations of Citizens" (2016) 6, Aquatic Procedia, 15-22. 
generally into the process that transform a territory, with consequences for peace, stability and the development in the country. Quite common in the Western world, especially in local contexts for urban or regional planning and management for instance, the participatory/collaborative approaches of governance certainly raise concerns, especially in large territories like a state, as in South Sudan. As Ansell and Gash emphasize, "high conflict situations characterized by low trust could still be managed collaboratively if the stakeholders were highly interdependent. Interdependence fosters a desire to participate and a commitment to meaningful collaboration, and it is possible to build trust in situations of high interdependence. By contrast, where interdependence is weaker, it will be difficult to effectively build trust. Stakeholders will engage in collaboration with one eye on alternative (non-collaborative) strategies.

If one stakeholder is threatening to withdraw from collaboration, the commitment of all stakeholders is likely to suffer, and it will be difficult to develop a sense of ownership, understanding, or trust." 84 Again, in the fragile and divided South Sudanese context, interdependence and ownership must be understood in a relative way, but they are necessary and deserve a special attention. Keeping these realistic views and the intrinsic limitations of the South Sudanese situation in mind, collaboration could be attempted in areas that are of common interest and less conflict-prone. This could perhaps be the case for service provision, embedding the modest decentralization presented above. Despite the limitations pointed by Ansell and Gash, critical services (like water or electricity, for example) could increase interdependence between the various stakeholders, henceforth establishing some kind of trust, opening the way to a limited collaboration that could be increased over time with other experiences.

It is nevertheless challenging to set in place collaborative processes when the people are poor and their levels of development are dangerously low. An overdependence on oil extraction and revenues are partly responsible for the majority of the people living in widespread poverty in South Sudan; it is also the fuel promoting the unequal distribution of wealth, encouraging the ones affected by discrimination (especially in oil-producing states, such as Unity State) to fight to defend

84 Ansell, C. and Gash, A., "Collaborative Governance in Theory and Practice," (2008) 18(4), Journal of Public Administration Research and Theory, 543-571. https://academic.oup.com/jpart/article/18/4/543/1090370/CollaborativeGovernance-in-Theory-and-Practice. 
their rights. Furthermore, as oil revenues are unreliable and keep decreasing over time, they have put the South Sudanese state in real difficulty. The country thus needs to urgently diversify its economy. It must be recognized, nevertheless, that economic diversification is a complex and long-term process, requiring policies, political will, a well thought out and structured development agenda, not to mention other factors like the participation of the private sector, foreign investments, and so on.

The examples of the Gulf States like Qatar show how challenging it is to diversify an economy away from an overreliance on extractive resources, even for a middle-income and stable country. For this reason, to diversify the South Sudanese economy, the government must concentrate on making realistic, focused, and limited efforts. These efforts may be concentrated on developing and supporting the agricultural sector, ${ }^{85}$ encouraging investment for mechanization, granting farmers access to loans (as was done in order to establish the Agriculture Bank in South Sudan), and reforming land ownership and rights to limit land grab. Choices have to be made to focus on a few promising crops of which coffee could be one. ${ }^{86}$ It is especially critical, at a first stage, to enhance food security in revising food production modalities and strategies, ${ }^{87}$ transforming agricultural practices and introducing a women/youth-centred approach.

Access to land and to other resources, especially the most critical ones, are a first necessary step to build peace and to develop South Sudan. This article, therefore, affirms that the South Sudanese longterm conflict is not an ethnic war between tribes, but a conflict for fair access to critical resources like oil, given the wealth and power that they engender. Access and rights to resources encompassing tribal divisions is fundamental: the access to water and electricity is perhaps needed to set in place any alternative economic activity that is not related to oil but can help in diversifying the economy and improving the livelihood of the population. This is in line with the decentralized service delivery objective presented above. It would contribute to

85 Tizikara, C., and Lugor, L.G.L., Post-Conflict Development of Agriculture in South Sudan; Perspectives on Approaches to Capacity Strengthening (Ministry of Agriculture od South Sudan, Juba) http://www.erails.net/images/fara/ secretariat/kigali-movement/file/Kigali\%20Movement/South\%20Sudan.pdf 86 Ibid.

87 ibid. 
reducing the reasons for conflict at the local level, decreasing the chances for militia to enrol members, and setting in place the minimal conditions for building trust and collaboration among different ethnic groups. This is a similar approach to the one adopted by Rwanda after the genocide, encouraging Hutu and Tutsi to create enterprises and work together.

These four features are certainly not enough; yet to achieve them is not even an easy process, as they are intertwined and ambitious goals. They are nevertheless a basis, a starting point in the right direction, to effectively and practically move the country away from war, step by step. For this reason, the next section focuses on the practical challenges and on the recommendations that would contribute towards building a good enough governance structure in South Sudan.

\section{CHALLENGES AND RECOMMENDATIONS}

Among the challenges making a good enough governance system difficult to achieve in South Sudan, three are particularly critical and representative of the diverse needs and difficulties with which the country is confronted, coming out as they are from decades of conflict and instability.

As underlined in previous sections, the lack of political will by the government could bedevil and jeopardize any genuine effort to improve the current situation in South Sudan. At the same time, institutional and individual capacity gaps are also deep and make difficult any attempt to improve the political and economic status of the country, according to what has been previously indicated. The shortage of financial resources to set in place policies and projects and to finance what is required to implement them is also critical.

These are three among the numerous and diverse challenges limiting the peace and development process in the country. In line with the good enough approach presented in this article, it is asserted here that these enormous challenges cannot completely be solved at once. Henceforth the recommendations offered are limited steps to get the transformative process started.

First, against the lack of political will, encouraging local leadership could be a critical step. Global leaders like Arkebe Okubay and Joan Clos have demonstrated that national and international leadership may arise from the local and, especially, the urban level. Henceforth, finding strong, capable, and determined majors for the larger or more important 
cities in the country could launch the process at the local level and subsequently help the national level to move accordingly. ${ }^{88}$

Second, building institutional and individual capacities is a huge goal per se, something too enormous that South Sudan cannot pretend to achieve on the short term. It has nevertheless shown in other post-conflict and fragile African states that building policy research capacities is a crucial requirement that national and foreign stakeholders can agree to finance and support in various ways. It is perhaps what has been recently pointed out in the Democratic Republic of Congo as necessary for state building.

Finally, creating financial resources and employment is again another huge and multi-layered task, but perhaps encouraging and sustaining small and medium entrepreneurship in the agricultural sector is a much more limited goal in line with what has been previously indicated and in accordance with what other African countries (like Zambia just to quote one) and regional economic communities (like COMESA for example) are doing. This is also similar to the measures that countries in the Gulf are promoting, recognizing that entrepreneurship (and especially green entrepreneurship) is a critical requirement for economic diversification and sustainable economic growth.

These recommendations are modest, but certainly not easy tasks. They would not solve all the problems of South Sudan, but they would hopefully set in motion some other complementary measures and processes towards a similar modest goal: a limited but positive good enough governance process, progressively improving itself over time.

\section{CONCLUSION}

The long South Sudanese history of conflicts and difficulties to achieve a status of sustainable peace in the country has been largely studied in the literature. Poor political governance is at the core of gaps and problems incessantly pushing the country back into conflict, even when some peace agreement seems to be achieved and agreed. Issues of accountability and transparency, state and institutions building, leadership commitment and determination are linked to political

88 Oqubay, A., Made in Africa: Industrial Policy in Ethiopia (Oxford: Oxford University Press 2015); Mike Herd, "We have lost the science of building cities" - meet Joan Clos, the unofficial world leader for cities" The Guardian (18 April 2016) <https://www.theguardian.com/cities/2016/apr/18/lost-science-buildingcities-joan-clos-un-habitat> 
governance and remain problematic at the present time because of the fragile and deficient status of the state.

For this reason, this article has emphasized the need for difficult contexts affected by conflicts like South Sudan (and for developing countries in general) to abandon utopic ideas to reach some sort of idealistic good governance in a short time, as the gap between the present situation and the goal to be achieved is too important. It consequently calls for a good enough governance framework that is not only a theoretical vision and position, but, more importantly, a mindset and a policy perspective, inviting local institutions, stakeholders, international donors, and practitioners involved on the ground in these contexts to select and prioritize a few modest and reachable objectives, to visibly improve the situation in the country in the short run. Focusing on limited, precise, and realistic goals is a necessity and a first step towards a good enough governance status, decreasing widespread poverty, delivering some basic services, and giving some minimum livelihood to the population through agriculture, for example, will surely enhance the food insecurity in the country dramatically.

Given the specific situation and history of South Sudan, any good enough governance attempt must prioritize a territorial focus, and consequently humane governance at the local level, as a critical condition. In fact, as earlier stated, South Sudan has been and keeps struggling to find an appropriate equilibrium between a centralized form of government and a real decentralized administration. The division into states, their number, their boundaries, their names, and ultimately, their definition have been changing over time, proving that there are interests and divergences, impeding the efforts to find a state system on which to build some ownership and trust among the different groups and stakeholders. The differences are so strongly defined to incessantly unleash violence and conflicts, as there are important economic interests behind the division of the national territory. Setting aside these ambitions for now and focusing on local service delivery of a few basic services could be a means to building a primary decentralization process. It would furthermore be in line and connected to the other actions towards collaboration among different social and ethnic groups, encouraging small entrepreneurship as a practical tool to start diversifying the economy.

A good enough territorial and economic governance does not exist yet in South Sudan, but it could be achieved as a first critical effort towards building sustainable peace in the country. 